Original Artical

\title{
A Study To Find Out The Correlation Between The Right And Left Hamstring Length In Both Genders To Determine The Prevalence Of Hamstring Tightness Among College Students.
}

\section{Dipesh Thakur', Sumi Rose ${ }^{2}$}

${ }^{1}$ BPT Final Year Student, ${ }^{2}$ Assistant Professor, Department of Physiotherapy, Acharya Institute of Health Sciences, Bangalore.

*Corresponding Author : Sumi Rose, Assistant Professor, department of physiotherapy, Acharya Institute of Health Sciences, Bangalore. E-mail : rosempt@yahoo.com.

Received

: 20.07.2016

Review Completed : 28.09.2016

Accepted

$: 27.10 .2016$

Keywords : Hamstring tightness, flexibility, Muscle, Overuse injuries.

\begin{tabular}{|c|}
\hline Access this article online \\
\hline Quick Response Code \\
\hline
\end{tabular}

Abstract:

Objectives : The purpose of this study is to find out the correlation between the right and left hamstring length in both genders to determine the prevalence of hamstring tightness among college students.

Methods : $\mathrm{N}=100$ subjects were recruited and screened on the basis of inclusion and exclusion criteria. 80 healthy college students were recruited between the age group of 18 to 25 years, sit and reach test was done among the students.

Result : The results stated that there is no statistically significant difference between the right and the left hamstring length in both genders and showed high correlation between the hamstring length of right and left of both groups. Chi square test was done and found that there is statistically significant difference between both the hamstring length of both the genders. The left hamstring of male had severe tightness of $27.50 \%$ and the right hamstring of female subjects had severe tightness of $45 \%$.

Conclusion : The study results concludes that there is significant correlation between the right and the left hamstring length in both groups but there is no correlation of hamstring length when compared with right hamstring length between groups and left hamstring length between groups. Male subjects had comparatively greater tightness in left hamstring and female subjects had right Hamstring tightness. Linear prevalence of Hamstring tightness is greater in female subjects when compared to male subjects.

\section{Introduction}

Hamstring injury is a strain or tear to the tendons or large muscle at the back of the thigh. It is common injury in athletes.

Physical fitness plays an important role in maintaining a good health. ${ }^{[1-3]}$ Lack of physical fitness is one of the reasons for the increase in childhood obesity in last two decades ${ }^{[2]}$.Flexibility is described as the ability to move a joint through its complete range of motion. It is the extensibility of muscle as well as the non- contractile tissues, such as joint capsule, ligaments, and tendons. ${ }^{[4]}$ Inflexibility screening field test, the most common used measure is the sit- and Reach test (SRT). ${ }^{[5,}$ SRT are commonly used to evaluate the hamstring and lower back flexibility. ${ }^{[7]}$
Maintaining Hamstring and low back flexibility may prevent acute and chronic musculoskeletal injuries and low back problems, postural deviations, gait limitation, and risk of falling. ${ }^{[8]}$ The Hamstring muscles and the measure of their length is due to certain dysfunction: patellofemoral joint dysfunction, pubic pain, low back pain (LBP) and postural deviations. $\left[{ }^{9-14}\right]$ In older adults tight Hamstrings can lead to reduced stride length and walking speed, which in turn can cause problems with dynamic balance.

The forward reach score does not distinguish between the contributions of the lumbar and thoracic spine and the hip joints during reaching activity ${ }^{[15]}$ The lack of hamstring muscles extensibility conditions a decrease in pelvic mobility (Kendall ET al.2005.Inflexible muscle can make the 
Musculotendinous unit susceptible to injury and can lead to some pathological conditions at the joint ${ }^{[2,3,6,15-17] .}$ Flexible muscles permit proper pelvic rotation. Decrease disc compression and avoid excessive stretch of musculatures. Therefore, when individuals with low hamstring extensibility perform a maximal trunk flexion with knees extended an increase in spinal flexion and posterior pelvic tilt occurs.

The main factors that seem to affect the validity of SR tests to estimate Hamstring extensibility are the differences in length proportion between the upper and lower limbs. Hamstring extensibility was associated with the decrease range of motion flexion of the pelvis and lumbar angle and the increased flexion of motion of the thoracic angle.

\section{Objectives}

Research Question and Problem : Is there any correlation between the right and left hamstring length in both genders which determine the prevalence of hamstring tightness among college students?

Objectives of the study : To find correlation between the right and left Hamstring length in both genders to determine the prevalence of Hamstring tightness among the college students.

\section{Hypothesis}

Null hypothesis $\left(\mathbf{H}_{0}\right)$ : There is no significant correlation between the right and left Hamstring length within and between both genders.

Null hypothesis $\left(\mathbf{H}_{0}\right)$ :There is no prevalence of Hamstring tightness among college students.

Research hypothesis $\left(\mathbf{H}_{1}\right)$ : There is significant correlation between the right and left Hamstring length within and between both genders.

Research hypothesis $\left(\mathbf{H}_{2}\right)$ : There is significant prevalence of Hamstring tightness among college students

\section{Methodology}

Source of Data: Data was collected from Acharya institute of Health Sciences.
Study design : Cross sectional design

Sample size : 100 college students

Study Sample : Healthy college students

Sampling design : Convenient sampling
Inclusion Criteria
o Normal Healthy college students
- Participants with age group 18 - 25 years
- Male and female
o Students willing to participate in this study.

\section{Exclusion Criteria \\ 0 Recent history of fracture or sprain. \\ o History of any other Neurologic M usculoskeletal problems. \\ 0 Recent surgeries around hip and knee joint.}

Tools used in this study
0 Inch tape
0 Couch

\section{Procedure}

100 healthy subjects $(n=100) 50$ male and 50 female were included in the study age group 18 to 25 years. Written consent was obtained from all the 100 subjects. Each subject was screened for, and excluded if the subjects had not met the inclusion criteria and $n=80$ included in the study. Then the purpose of study was explained to the subjects. Followed by, demographic information including name, gender and age was documented.

\section{Testing position}

\section{Subject position: Long sitting position}

M ethod of Testing: The subjects were told to sit in the long sitting position over the couch. And maximally bends forward and try to touch the toes with the knee extended. M easurement was taken from the middle finger to the toes with inch tape. The measurement was recorded in inches for both right and left extremities in both genders.

Data Analysis: $\mathrm{N}=100$ participants were willing to be the part of the study out of which $n=80(N=40$ males $\& N=40$ females) subjects were screened and completed the study. All data was analyzed using SPSS .V. 16.Software. 
Flow chart for the recruitment of the study sample

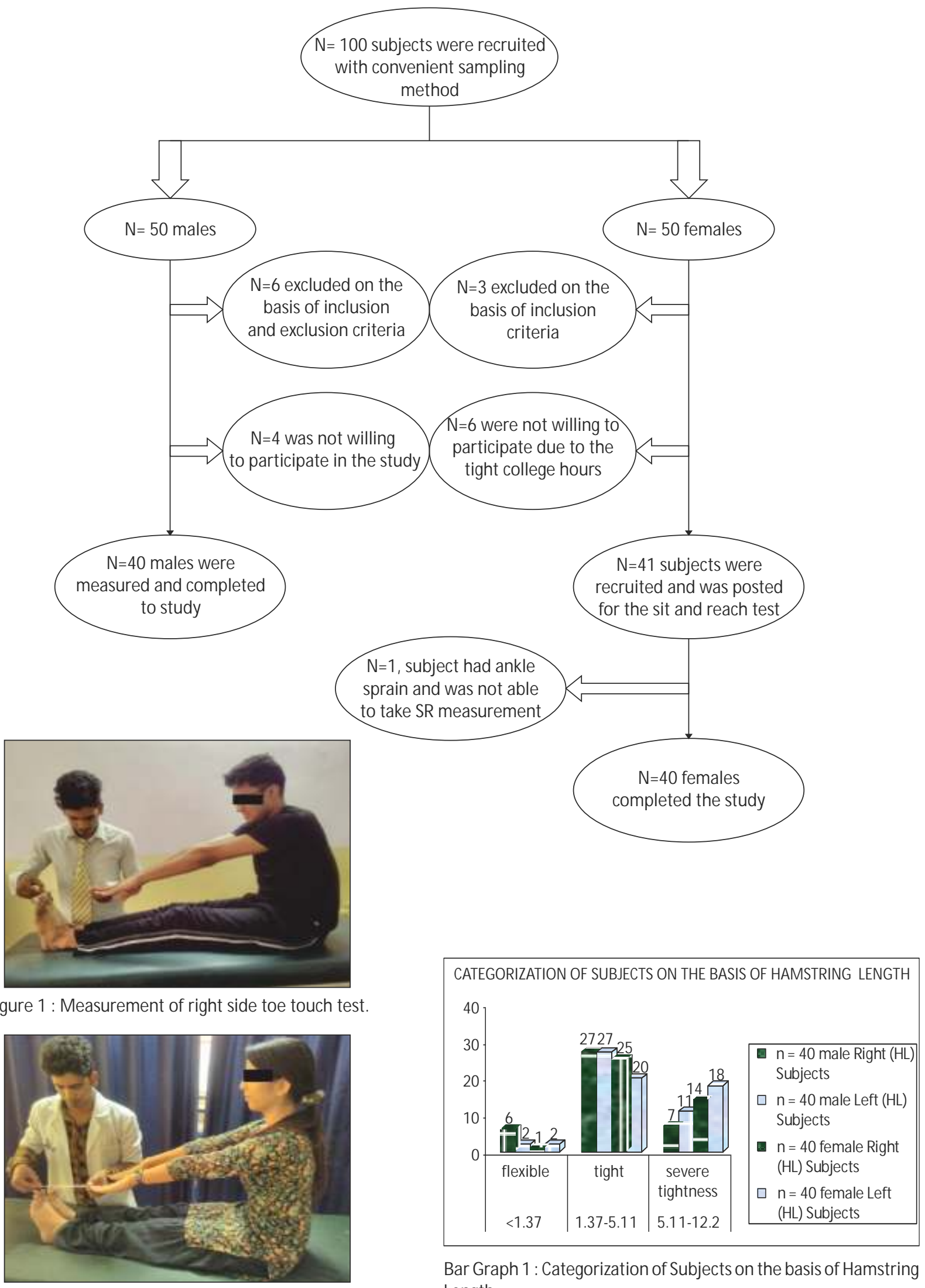

Figure 1 : M easurement of right side toe touch test.

Figure 3 : M easurement of left side Toe touch for sit and reach test.
Bar Graph 1 : Catego rization of Subjects on the basis of Hamstring Length 
Descriptive statistics were reported as mean $(95 \%$ confidence interval), range, SEM and percentage.

To find the correlation between the two groups the spearman rank correlation test was used. Significance level was set at $\mathrm{P}<0.05$.The chi square statistics was used to test the difference between the hamstring flexibility in right and left hamstring of both gender.

\section{Result}

The results stated that there is no statistically significant difference between the right and the left hamstring length in both male and female and showed high correlation between the hamstring length of right and left of both male and female subjects.

Between the groups the chi square test was done to find the difference and found that there is statistically significant difference in both the hamstring length in both the genders.

There is negative correlation (-.082) with no statistically significant difference between the hamstring length of both male and female subjects

Table No. 1: Descriptive Statistics:

\begin{tabular}{|c|c|c|c|c|}
\hline \multicolumn{5}{|c|}{ Statistics } \\
\hline \multirow{2}{*}{ Valid } & \multicolumn{2}{|c|}{ MALE } & \multicolumn{2}{|c|}{ FEMALE } \\
\hline & RT & LT & RT & LT \\
\hline & \multicolumn{2}{|c|}{40} & \multicolumn{2}{|c|}{40} \\
\hline Mean \& SD & \multicolumn{2}{|c|}{$21.0 \pm 1.4$} & \multicolumn{2}{|c|}{$19.6 \pm 1.5$} \\
\hline M ean & 4.4500 & 4.9125 & 3.4000 & 3.9125 \\
\hline Std. Error of M ean (SEM) & .39500 & .42626 & .34493 & .33440 \\
\hline M edian & 4.0000 & 4.7500 & 3.0000 & 3.7500 \\
\hline Mode & 2.00 & $2.00^{\mathrm{a}}$ & $1.00^{\mathrm{a}}$ & 2.50 \\
\hline Std. Deviation (SD) & 2.49820 & 2.69588 & 2.18151 & 2.11493 \\
\hline Variance & 6.241 & 7.268 & 4.759 & 4.473 \\
\hline Range & 9.00 & 11.50 & 9.50 & 9.50 \\
\hline Minimum & 1.00 & .50 & 1.00 & 1.00 \\
\hline ax & 10.00 & 12.00 & 10.50 & 10.50 \\
\hline
\end{tabular}

Table 2 : Chi-Square test Statistics for $M$ ale

\begin{tabular}{|l|l|l|l|}
\hline & $\mathrm{N}=40$ & Right & Left \\
\hline Chi- Square & & $13.300^{\mathrm{a}}$ & $9.000^{\mathrm{b}}$ \\
\hline Df & & 12 & 13 \\
\hline Asymp. sig & & .348 & .773 \\
\hline
\end{tabular}

A.13 cells (100.0\%) have expected frequencies less than 5 . The minimum expected cell frequency is 3.1 .
B.14 cells (100.0\%) have expected frequencies less than 5.The minimum expected cell frequency is 2.9

Table 3 : Spearman's Correlation tests for Male

\begin{tabular}{|l|c|c|}
\hline M ale & Right & Left \\
\hline Spearman's Rho Right (Correlation coefficient) & 1.000 & $0.953^{* *}$ \\
\hline Sig. (2- tailed) & & .000 \\
\hline $\mathrm{N}$ & 40 & 40 \\
\hline Left (Correlation coefficient) & $0.953^{* *}$ & 1.000 \\
\hline Sig. (2- tailed) & 0.000 & \\
\hline $\mathrm{N}$ & 40 & 40 \\
\hline$* *$ Correlation issignificant at the level (2-tailed) & \multicolumn{2}{l}{} \\
\cline { 2 - 3 }
\end{tabular}

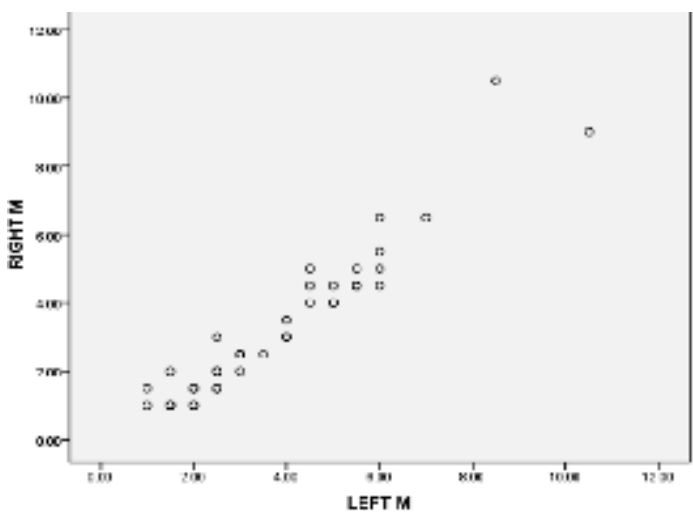

Graph 1 : shows that there is positive correlation between the right and left hamstring length in male.

Table 4 : Chi- Square Statistics test for Female

\begin{tabular}{|l|l|l|l|}
\hline & $\mathrm{N}=40$ & Right & Left \\
\hline Chi-Square & & $11.300^{\mathrm{a}}$ & $14.400^{\mathrm{a}}$ \\
\hline Df & & 17 & 16 \\
\hline Asymp. Significance & & 0.841 & 0.569 \\
\hline
\end{tabular}

A.18 cells (100\%) have expected frequencies less than 5 . The minimum expected cell frequency is 2.2 .

B.17 cells (100\%) have expected frequencies less than 5 . The minimum expected cell frequency is 2.4

Table 5 : Spearman's Correlation Test for female

\begin{tabular}{|l|l|l|}
\hline Females & Right & Left \\
\hline $\begin{array}{l}\text { Spearman's Rho Right } \\
\text { (Correlation coefficient) }\end{array}$ & 1.000 & $0.893^{* *}$ \\
\hline Sig. (2- tailed) & & .000 \\
\hline $\mathrm{N}$ & 39 & 39 \\
\hline Left (Correlation coefficient) & $0.893^{* *}$ & 1.000 \\
\hline Sig. (2- tailed) & .000 & \\
\hline $\mathrm{N}$ & 39 & 40 \\
\hline
\end{tabular}

** Correlation is significant at the level (2-tailed 


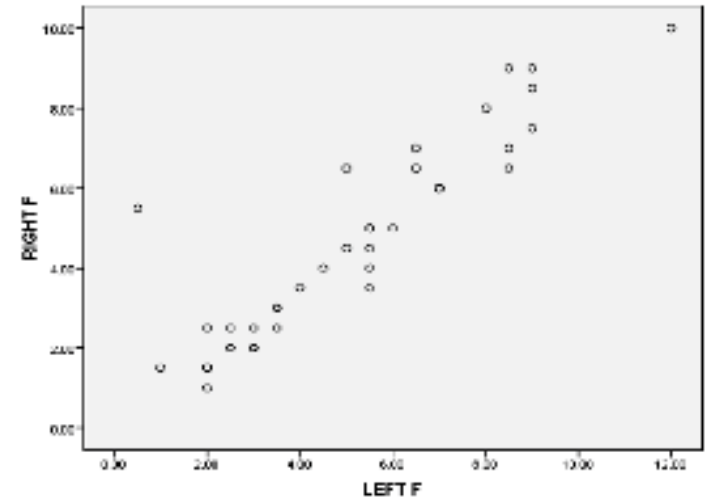

Graph 2 : Shows that there is significant correlation between the right and left hamstring length in female.

Table 6 : Spearman's rho correlation of right hamstring for both Male and Female

\begin{tabular}{|l|c|c|}
\hline & Right-M ale & Right-Female \\
\hline $\begin{array}{l}\text { Spearman's Rho Right } \\
\text { (Correlation coefficient) }\end{array}$ & 1.00 & 0.023 \\
\hline Sig. (2- tailed) & & 0.888 \\
\hline N & 40 & 40 \\
\hline Right (Correlation coefficient) & 0.023 & 1.00 \\
\hline Sig. (2- tailed) & 0.888 & \\
\hline N & 40 & 40 \\
\hline
\end{tabular}

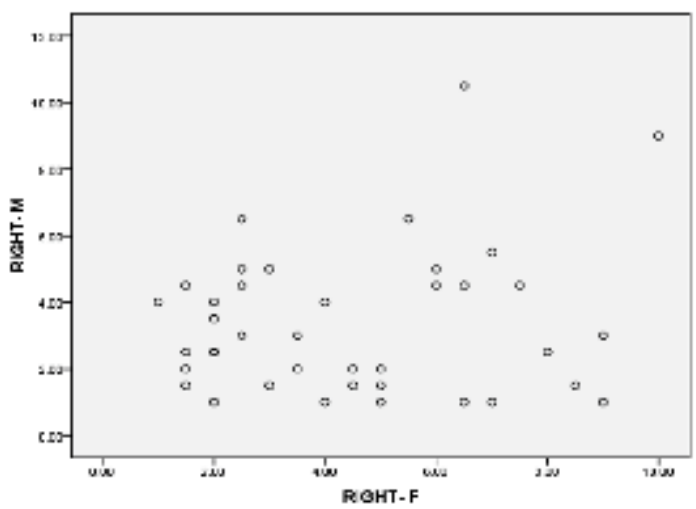

Graph 3 : Shows that there is no significant correlation between the right hamstring length in male and female subjects.

Table 7 : Spearman's rho Correlation of left Hamstring for both $M$ ale and Female

\begin{tabular}{|l|c|c|}
\hline & Left- Male & Left Female \\
\hline $\begin{array}{l}\text { Spearman's Rho Left } \\
\text { (Correlation coefficient) }\end{array}$ & 1.00 & -0.082 \\
\hline Sig. (2- tailed) & & 0.615 \\
\hline $\mathrm{N}$ & 40 & 40 \\
\hline Left (Correlation coefficient) & -0.082 & 1.00 \\
\hline Sig. (2- tailed) & 0.615 & \\
\hline $\mathrm{N}$ & 40 & 40 \\
\hline
\end{tabular}

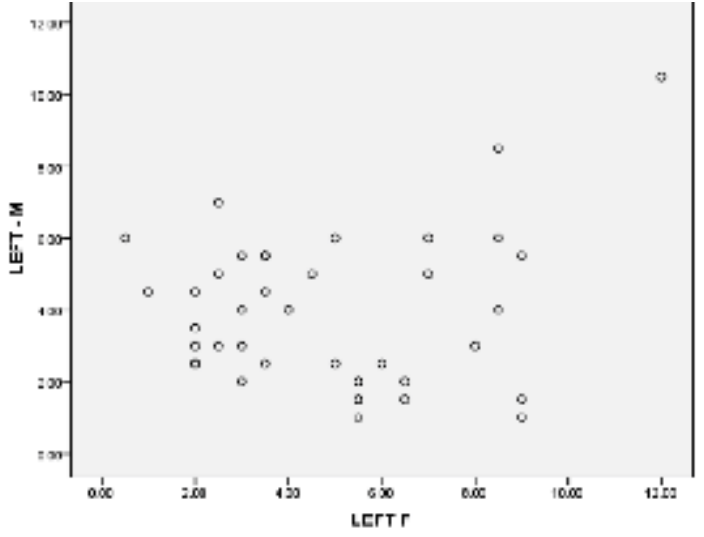

Graph 4 : Showing there is no significant correlation between the left hamstring length in male and female subjects.

Table 8 : Categorization of Subjects on the basis of Hamstring Length

\begin{tabular}{|l|l|c|c|c|c|}
\hline \multicolumn{6}{|c|}{ Categorization of Subjects on the basis of Hamstring Length } \\
\hline \multicolumn{2}{|c|}{ Hamstring length } & \multicolumn{2}{|c|}{$\mathbf{N =}$ Male } & \multicolumn{2}{c|}{$\mathbf{N = 4 0 ~ F e m a l e ~}$} \\
\hline Inches & $\begin{array}{l}\text { Interpre- } \\
\text { tation }\end{array}$ & $\begin{array}{c}\text { Right }(\mathrm{HL}) \\
\text { subjects }\end{array}$ & $\begin{array}{c}\text { Left }(\mathrm{HL}) \\
\text { subjects }\end{array}$ & $\begin{array}{c}\text { Right (HL) } \\
\text { subjects }\end{array}$ & $\begin{array}{c}\text { sefts (HL) } \\
\text { subjects }\end{array}$ \\
\hline$<1.37$ & Flexible & 6 & 2 & 1 & 2 \\
\hline $1.37-5.11$ & Tight & 27 & 27 & 25 & 20 \\
\hline $5.11-12.2$ & $\begin{array}{l}\text { Severe } \\
\text { tightness }\end{array}$ & 11 & 11 & 14 & 18 \\
\hline
\end{tabular}

Table 9 : Percentage of Hamstring flexibility and tightness $n=80$ )

\begin{tabular}{|l|c|c|c|c|}
\hline Hamstring length $\mathrm{N}=80$ & \multicolumn{2}{|c|}{ Male } & \multicolumn{2}{c|}{ Female } \\
\hline Percentage \% & Right \% & Left \% & Right \% & Left \% \\
\hline Flexible & 15 & 5 & 3 & 5 \\
\hline Tight & 67.50 & 67.50 & 63 & 50 \\
\hline Severe tightness & 17.50 & 27.50 & 35 & 45 \\
\hline
\end{tabular}

\section{Discussion}

The aim of the study was to find out the correlation between the right and left Hamstring length in both genders to determine the prevalence of Hamstring tightness among the college students.

80 subjects were recruited by convenient sampling method on the basis of inclusion and exclusion criteria from Acharya institute of health sciences which included 40 males and 40 females' subjects. Hamstring tightness was measured with the help of inch tape under Sit and Reach test technique. Subjects tried to touch the toes maximally bend forward without flexing knees. In this study M ean and Standard deviation was recorded separately for $\mathrm{M}$ ale and Female right and left side $(2.9 \pm 3.4$ and $2.1 \pm 3.9)$ and $(2.5$ \pm 4.5 and $2.7 \pm 4.9$ ). 
The result states that there is no statistically significant difference between the right and the left Hamstring length in male as well as in female subjects. There is positive correlation between the right and left Hamstring length in male as well as in female subjects.

There is no significant correlation between the right Hamstring which is measured in male and female subjects. There is no significant correlation between the left Hamstring length in male and female subjects.

The subjects were divided into the range of flexibility to severe tightness. Out of 40 subjects in male 2 subjects in left and 6 subjects in right were flexible who had the sitand reach test measurement, $<1.37$ inches whereas 27 out of 40 both Hamstring tightness measurement ranging from 5.11 to 12.2 which accounts for $68 \%$ of total population. 7 subjects in right and 11 subjects in left had severe Hamstring tightness which accounts for $17.5 \%$ in right and 27.5\% left Hamstring length of total population.

In female1 subject in right and 2 subjects in left accounting for $2.5 \%$ in right and $5 \%$ in left were flexible and 25 subjects in right and 20 subjects in left were having tightness accounting for around $63 \%$ in right and $50 \%$ in left Hamstring length of total study population. About 14 subjects accounting for $35 \%$ and 18 subjects in left accounting for $45 \%$ were having severe tightness in Hamstring.

The current study gives a clear indication that in males left Hamstring is tighter when compared to right Hamstring and in females right Hamstring has increased tightness when compared to left Hamstring muscle.

\section{References}

1. Watter RT, Neil F, Linda SP. American College of Sports Medicine. ACSM 's Guidelines for Exercise Testing and Prescription.9th Ed. Philadelphia: Lippincott Williamsand Wilkins 2013

2. Fabunmi A, Akaraiwe, Chiamaka A, Akosile. Hamstring Flexibility: Relationship between straight leg raise and back Saver sit-and-reach tests. ICHPER-SD .2008:14-7

3. Corbin C, Pangrazi B. The health benefits of physical activity. J Phys Act Fit Res Dig 1993; 1:1-7

4. Cornbleet SL, Woolsey NB. Assessment of hamstring muscle Length in school-aged children using the sit-and-reach test And the inclinometer measure of the hip joint angle. (1996), 76:850-5

5. Chung JW, Chung LM, Chen B. The impact of life style on the physical
The tightness in Hamstring length may be due to the lack of regular flexibility exercises or not appropriate physical activities.

The college students have more or less sedentary life style as they appear to be more in academic activities than into physical activities. Colleges should increase the physical activity periods for the Students

\section{Limitation}

1. Unavoidable minimal human error during the measurement with inch tape can be overcome by using digital scales.

2. Height and weight was not considered in this study

3. The study did not screen the subjects who were indulged in the physical activities which might have also influenced the study.

\section{Recommendation}

1. Future studies should consider large sample size.

2. Randomized controlled studies have to be incooperated to improve flexibility of both Hamstring muscles Right and Left.

\section{Conclusion}

The study results concludes that there is significant correlation between the right and the left hamstring length in both groups but there is no correlation of hamstring length when compared with right hamstring length between groups and left hamstring length between groups. Male subjects had comparatively greater tightness in left hamstring and female subjects had right Hamstring tightness. Linear prevalence of Hamstring tightness is greater in female subjects when compared to male subjects.

fitness of primary school children.J Clin Nurs (2009); 18:1002-9.

6. Milliken LA, Faigenbaum AD, Loud RL, Westcott WL. Correlates of upper and lower body muscular strength in Children Strength Cond $\operatorname{Res}(2008) ; 22: 1339-46$.

7. Holt LE, Pelham TW, Burke DG. Modifications to the standard sit and reach flexibility protocol. J Athl Train. 1999; 34(1):43-7

8. ACSM. Guidelines for exercise testing and prescription.6th Ed.Baltimore, Lippincott, Williams\& Wilkins, (2000):85-8.

9. Delee JC, Drez D, Miller MD. Orthopaedic sports medicine: principles and practice. Philadelphia: Saunders; (2003).

10. Witvrouw E, Danneels L, Asselman P, D'Have T, Cambier D. Muscle flexibility as a risk factor for developing muscle injuries in male 
professional soccer players. A prospective study. Am J Sports Med. 2003; 31(1):41-6.

11. Witvrouw E, Bellemans J, Lysens R, Danneels L, Cambier D. Intrinsic risk factors for the development of patellar tendinitis in an athletic population. A two-year prospective study. Am J Sports Med. 2001; 29(2):190-5.

12. Hartig DE, Henderson JM . Increasing hamstring flexibility decreases lower extremity overuse injuries in military basic trainees. Am J Sports Med. 1999; 27(2):173-6.

13. Woods C, Hawkins RD, M altby S, Hulse M, Thomas A, Hodson A. The football association medical research programme: an audit of injuries in professional football-analysis of hamstring injuries. Br J Sports M ed. 2004; 38:36-41.

14. Busquet L. Les chaines musculaires T.3; La pubalgie. Paris: FrisonRoche; 2001

15. Cornbleet, S.L. and Woolsey, N.B. Assessment of Hamstring muscle length in school-aged children using the sit-and-reach test and the inclinometer measure of hip joint angle. Physical therapy1996; 76: 850-85

16. Suzann K, Robert J, Margo N. Physical therapy for children.4th Ed. Linda Duncan.USA; 2012.P 205-38.

17. Kawano M M , Ambar G, Oliveira BI, Boer M C, Cardoso AP, Cardoso JR. Influence of the gastrocnemius muscle on the Sit-and-reach test assessed by angular kinematic analysis. Rev Bras Fisioter2010; 14:105.

18. Lopez-M iñarro PA, Andujar PS, Rodriguez Garcna PL. A comparison of the sit-and- reach test and back saver sit and- reach test in university students. J Sports Sci M ed 2009; 8:116-22.

19. Cynthia C. Norkin Joint structure and functions $5^{\text {th }}$ Ed Jaypee New Delhi 2011.

20. Cunningham's M anual of practical Anatomy, GJ Romanes C.B.E Oxford University New York 15 Ed 1986.

21. Bhoomita Gadhiya, Watson Arulsingh, Asir john Samuel Difference between the back saver sit-and reach test and modified back saver sitand reach test in estimating hamstring flexibility among primary school children Maharasi Marekandeswar university Haryana India (2015) Archives of M edicine and Health Sciences. 2014; 2:2

22. Pedro A. Lopez- M inarro Pilar Sanaz de Baranda Andujar and Pedro L. Rodriguez- Garcia:- A comparision of the sit- and reach test and the back- saver sit- and reach test in university students.J ournal of Sports Science and M edicine .2009; 8:116 - 122

23..M arcio M. Kawno, Gabriel Ambar, Beatriz I. R. Oliveira, Marcela C. Boer Jefferso and R. Cardoso Garcia: Influence of the gastrocnemius muscle on the sit- and reach test assessed by angular kinematics analysis 2009;14

24. Odunaiyan. A., Hsmzat T.K., Ajayi O.F. The Effects of Static Stretch Duration on the Flexibility of Hamstring Muscles. African Journal of Biomedical Research, 2005; 8:79-82

25. G Baltaci, N UN, V Tunay, a Besler, S Gerceker Comparison of three different sit and reach tests for measurement of hamstring flexibility in female university students. Br J Sports M ed 2003; 37:59-61 